\title{
Stunting is a major risk factor for overweight: results from national surveys in 5 Arab countries
}

A. El Taguri, ${ }^{1,2}$ F. Besmar, ${ }^{1}$ A. Abdel Monem, ${ }^{3}$ I. Betilmal, ${ }^{4}$ C. Ricour ${ }^{1}$ and M-F. RollandCachera $^{5}$

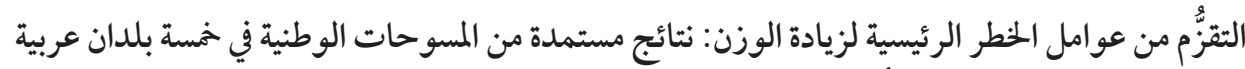

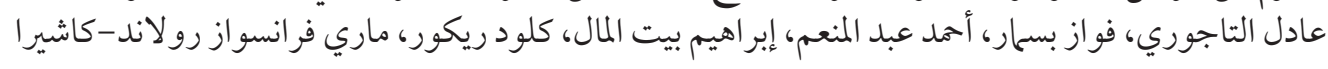

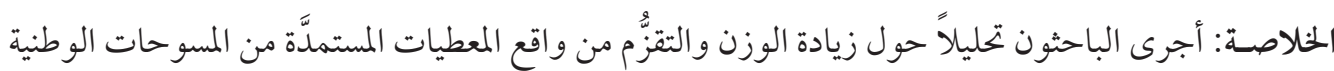

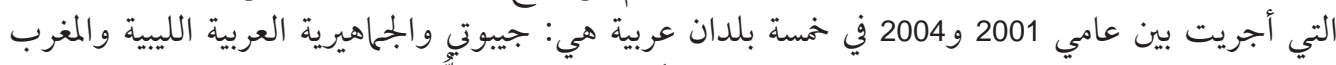

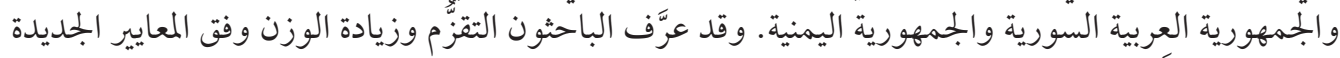

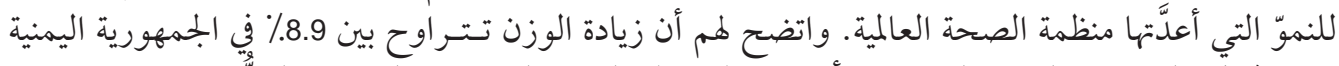

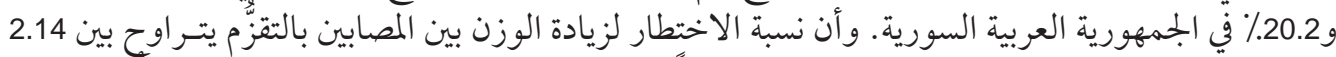

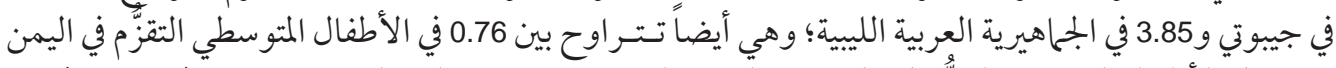

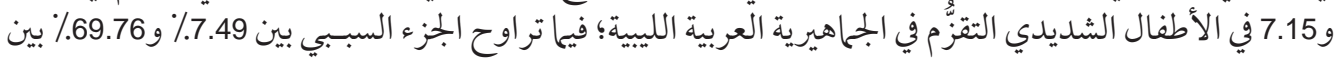

ABSTRACT We analysed data on overweight and stunting from large national surveys performed between 2001 and 2004 in 5 Arab countries (Djibouti, Libyan Arab Jamahiriya, Morocco, Syrian Arab Republic and Yemen). Overweight and stunting were defined according to new WHO growth standards. Overweight ranged from $8.9 \%$ in Yemen to $20.2 \%$ in Syrian Arab Republic. The risk ratio (RR) for overweight in stunted children ranged from 2.14 in Djibouti to 3.85 in Libyan Arab Jamahiriya. RR ranged from 0.76 in mildly stunted children of Yemen to 7.15 in severely stunted children in Libyan Arab Jamahiriya. Etiological fraction in the population ranged from $7.49 \%$ to $69.76 \%$.

\begin{abstract}
Le retard de croissance comme important facteur de risque de surpoids : résultats d'études nationales dans cinq pays arabes

RÉSUMÉ Nous avons analysé les données sur le surpoids et le retard de croissance provenant de vastes études nationales réalisées entre 2001 et 2004 dans cinq pays arabes (Djibouti, Jamahiriya arabe libyenne, Maroc, République arabe syrienne et Yémen). Le surpoids et le retard de croissance étaient définis conformément aux nouvelles normes de croissance de l'OMS. Le taux de surpoids variait de $8,9 \%$ au Yémen à 20,2\% en République arabe syrienne. Le rapport des risques (RR) de surpoids chez les enfants présentant un retard de croissance était compris entre 2,14 à Djibouti et 3,85 en Jamahiriya arabe libyenne. Ce rapport allait de 0,76 chez les enfants présentant un léger retard de croissance au Yémen, à 7,15 chez ceux présentant un important retard de croissance en Jamahiriya arabe libyenne. La fraction étiologique dans la population était comprise entre $7,49 \%$ et $69,76 \%$.
\end{abstract}

\footnotetext{
${ }^{1}$ Hôpital Necker Enfants Malades, Paris, France (Correspondence to A. El Taguri: tajoury@pediatrician.com) ${ }^{2}$ Department of Family and Community Medicine, Alfateh University, Tripoli, Libyan Arab Jamahiriya.

${ }^{3}$ Pan Arab Project for Family Health (PAPFAM), League of Arab States.

${ }^{4}$ World Health Organization Regional Office for the Eastern Mediterranean, Cairo, Egypt.

${ }^{5}$ Unité de Surveillance et d'Epidémiologie Nutritionnelle, Unité de Recherche et d'Epidémiologie

Nutritionnelle, Centre de Recherche en Nutrition Humaine lle-de-France, Paris, France.

Received: 12/09/07; accepted: 20/11/07
}

المجلة الصحية لشرق المتوسط، منظمة الصحة العالمية، المجلد الخنامس عشر، العدد ب، 9 +. 


\section{Introduction}

Malnutrition is a leading contributor to the global burden of disease [1]. Malnutrition refers not only to deficiency states, but also to excesses or imbalances in intake of energy, protein and/or other nutrients [2]. Globally, undernutrition is an underlying or associated cause in at least half of all childhood deaths [3]. On the other hand, overweight is becoming a public health problem even in many of the developing nations; the prevalence in some has reached even higher levels than in many industrialized countries [4,5]. Countries in the Middle East and North Africa have a high prevalence of overweight in children [6]. It has been reported that by the year 2020 , over $60 \%$ of the disease burden and mortality in developing countries will result from noncommunicable diseases as a consequence of the rising prevalence of overweight. Management of these diseases will be beyond the capacity of many of these nations [7].

Both undernutrition and overnutrition have a great impact on social, economic and health care systems. Both these forms of malnutrition can coexist [8]. Community interventions that are designed to prevent or treat one problem can exacerbate the other and displace the whole population curve to the right, generating a significant proportion of overweight and obese children [9]. In an individual child, the relation between stunting and overweight is not simply a situation of coexistence; epidemiological and experimental evidence is accumulating to indicate that there is a causal relationship [10]. On the other hand, in developed countries, an association was found between BMI and stature in children, with height and adiposity being positively related [11].

The aim of the present work was to assess the prevalence of overweight and stunting, and the association between stunting and overweight in children under 5 years of age based on available and comparable data from countries in the Eastern Mediterranean Region.

\section{Methods}

\section{Data source}

The study was a secondary analysis of data collected from nationwide surveys performed in the Eastern Mediterranean Region. The most recent and comparable data from surveys performed in the same time period were available for 5 countries from 2 different surveys. The data for the Syrian Arab Republic, Morocco, Djibouti and Yemen came from the Pan Arab Project for Family Health (PAPFAM). This project is a series of cross-sectional, nationally representative, 2-stage, stratified cluster sample surveys that were performed in the Region starting in 2001 [12]. Data from the Libyan Arab Jamahiriya came from the Multiple Indicator Cluster Sample Survey (MICS), which was a series of similar surveys performed in many countries around the world that was organized principally by the United Nations Children's Fund $[13,14]$. The series essentially assessed the achievement of different countries in fulfilling their commitment to goals agreed upon in the 1989 Convention on the Rights of the Child.

Data were collected in interviews with mothers during household visits using standard questionnaires, with a few modifications to conform to local disease and disease determinants patterns. The full set of questionnaires contained: items related to child health and its determinants such as vaccination, birth, and nutrition; items related to mother's health and reproductive history; and items on household characteristics and surrounding environment, such as the availability of a safe water supply, sanitation facilities, garbage collection, and wealth or assets of the families. 


\section{Outcome measures}

Weight, height and age were used to calculate $z$-scores of body mass index for age (BMI/A) and height for age (H/A) using the newly published growth charts from the World Health Organization (WHO) multiple centre growth reference study [15]. BMI was calculated by dividing the weight in kilograms by the square of the height in metres. Children were classified as obese if they had a BMI/A $z$-score greater than 2 standard deviations (SD) of the median of the WHO growth standards, and as stunted if they had a $\mathrm{H} / \mathrm{A} z$-score below -2 SDs of the median [15]. Unless stated otherwise, stunting refers to moderate and severe stunting. We also included in the same stage of analysis, mild stunting. This included children whose $\mathrm{H} / \mathrm{A} z$-score was $<-1$ but $\geq-2$ SDs. Wasting was diagnosed if the weightfor-height $(\mathrm{W} / \mathrm{H}) z$-score was $<-2$ SDs.

Household assets were used to construct an asset index as a proxy measure for socioeconomic status in 3 countries. For Djibouti and the Libyan Arab Jamahiriya, a socioeconomic classification that incorporated parents' occupation and education was used [16]. Each of the 5 populations was separately divided into 3 socioeconomic groups: privileged, intermediate and underprivileged. Independent variables used were basic epidemiological attributes such as age, sex, socioeconomic status, geographic region and urban/rural residence.

\section{Statistical analysis}

Data analysis was done using WHO Anthro 2005 software (WHO, Geneva, Switzerland), and SPSS for Windows, version 13. The WHO Anthro 2005 program considers $z$-score values for $\mathrm{W} / \mathrm{H}$ and $\mathrm{BMI} / \mathrm{A}<-5$ SDs as outliers, while for H/A and W/A it considers $z$-score values $<-6$ SDs as outliers. We used risk ratio (RR) to measure the association between being stunted and being overweight. This indicates the probability of being overweight in the stunted sub-sample divided by the probability of being overweight in the non-stunted subsample. Etiological fraction among the exposed (EFe) was calculated as (RR-1)/RR, while etiological fraction in the population (EFp) was calculated as $[\mathrm{Pe}(\mathrm{RR}-1)] /[\mathrm{Pe}$ $(\mathrm{RR}-1)+1]$, where Pe is the proportion of exposure to the risk factor in the population. EFe as such measures the proportion of overweight among stunted children that could be attributed to stunting, while EFp measures the proportion of overweight in the general population that could be attributed to stunting. Level of significance was set at $P<0.05$.

\section{Results}

Yemen had the lowest gross domestic product (GDP) and is classified by WHO as a very high prevalence area for underweight. The Libyan Arab Jamahiriya had the highest GDP. The Libyan Arab Jamahiriya, Syrian Arab Republic and Morocco are all classified by WHO as low prevalence areas for underweight. The highest proportion of urban dwellers was in the Libyan Arab Jamahiriya and Djibouti, while the lowest was in Yemen (Table 1).

Yemen had the highest prevalence of moderate to severe stunting $(57.6 \%)$. Djibouti had the highest prevalence of wasting (17.8\%), while the Libyan Arab Jamahiriya had the lowest rate of both wasting (4.8\%) and stunting (18.5\%). Overweight ranged from $8.9 \%$ in Yemen to $20.2 \%$ in the Syrian Arab Republic (Table 2).

Overweight was more prevalent in rural than in urban areas except in Morocco, while in the Syrian Arab Republic, overweight prevalence was higher in both urban and rural areas than in suburban areas.

المجلة الصحية لشرق المتوسط، منظمة الصحة العالمية، المجلد الخنامس عشر، العدد ب، 9 +. 


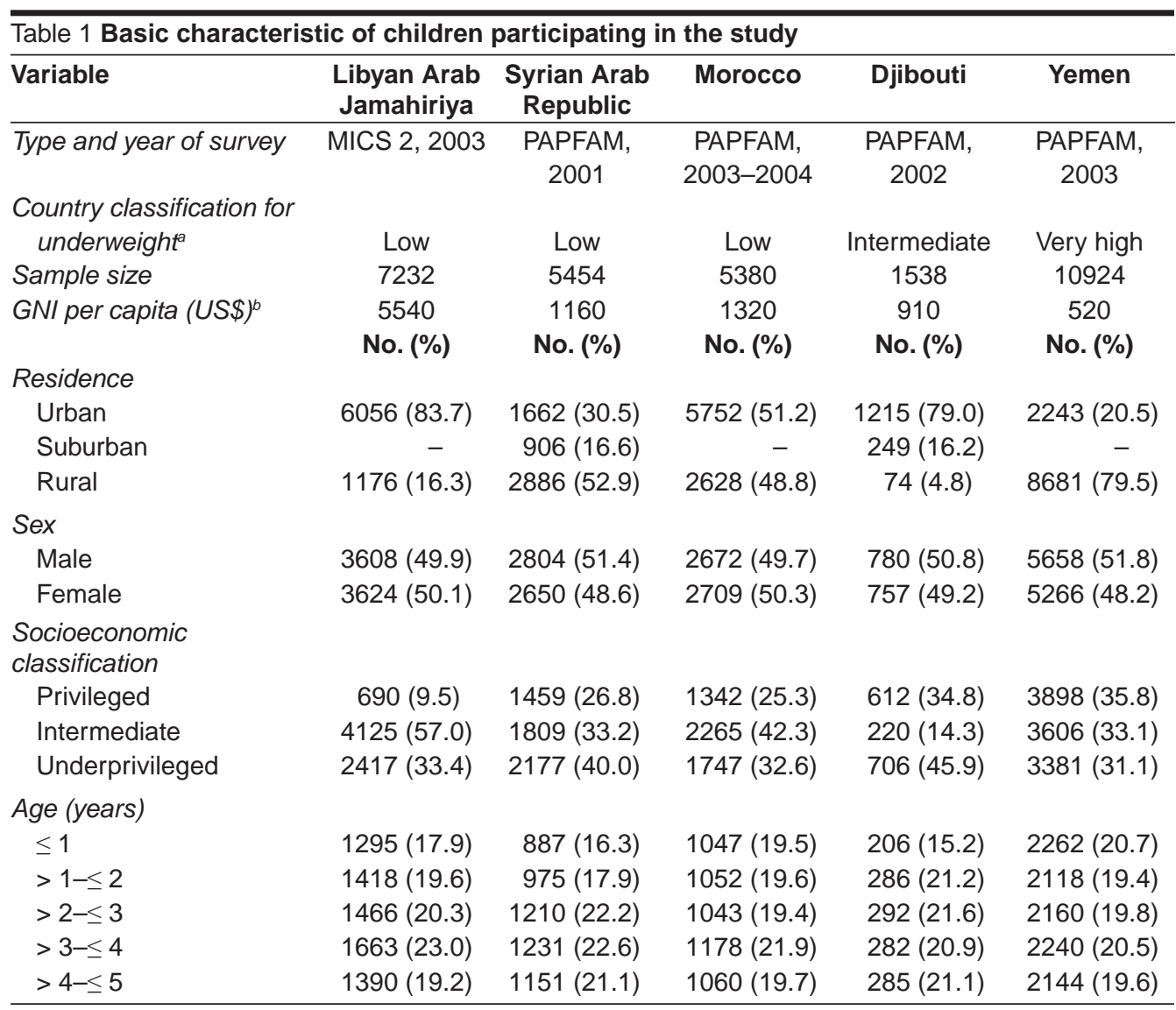

${ }^{a}$ Based on WHO Statistical Information System (http://www.who.int/whosis/data/Search.jsp, accessed 27 November 2008) and Global prevalence of underweight among children under age five. Map Design Unit of the World Bank (http://siteresources.worldbank.org/NUTRITION/Resources/281846-1131636806329/NutritionStrategyMaps.pdf, accessed 27 November 2008).

'Source: World Bank, 2003 [39].

$\mathrm{GNI}=$ gross national income.

The prevalence of overweight was highest in privileged groups in the Syrian Arab Republic and Djibouti, while it was highest in underprivileged groups in Morocco. In the Libyan Arab Jamahiriya and Yemen, it was highest in the intermediate group The highest regional prevalence of overweight in the Syrian Arab Republic was in Halab and Al-Raka (31.5\% and 47.8\% respectively), while in Morocco the highest regional prevalence was $23.2 \%$ in Fes-
Boulemane (complete regional data are not presented but are available on request). In Yemen, the prevalence of overweight was highest in Al-Maharah (22.5\%) and Ibb (20.7\%) governorates and in the Libyan Arab Jamahiriya it was highest in Tarhuna and Missallata region (24.4\%). Both stunting and overweight were more prevalent in boys than girls (Table 3 ).

Stunting prevalence was higher in rural areas in all countries and was higher in 


\begin{tabular}{|c|c|c|c|c|c|}
\hline Variable & $\begin{array}{c}\text { Libyan Arab } \\
\text { Jamahiriya } \\
\text { No. (\%) }\end{array}$ & $\begin{array}{c}\text { Syrian Arab } \\
\text { Republic } \\
\text { No. (\%) }\end{array}$ & $\begin{array}{l}\text { Morocco } \\
\text { No. (\%) }\end{array}$ & $\begin{array}{l}\text { Djibouti } \\
\text { No. (\%) }\end{array}$ & $\begin{array}{l}\text { Yemen } \\
\text { No. (\%) }\end{array}$ \\
\hline Overweight (> 2 BMI/A z-score) & $963(13.4)$ & $1100(20.2)$ & $832(15.5)$ & $137(10.2)$ & $975(8.9)$ \\
\hline Wasting $(<-2 \mathrm{~W} / \mathrm{H}$ z-score $)$ & $312(4.8)$ & $516(9.5)$ & $546(10.2)$ & $241(17.8)$ & $1920(17.7)$ \\
\hline Stunting & & & & & \\
\hline Mild $(<-1 \mathrm{H} / \mathrm{A} z$-score $)$ & $612(24.7)$ & $1135(20.8)$ & $1259(23.4)$ & $319(23.6)$ & $1974(18.1)$ \\
\hline $\begin{array}{l}\text { Moderate/severe }(<-2 \mathrm{H} / \mathrm{A} \\
z \text {-score })\end{array}$ & $1208(18.5)$ & $1640(29.4)$ & $1187(22.0)$ & $357(26.5)$ & $6297(57.6)$ \\
\hline Moderate (between -2 and -3 & & & & & \\
\hline $\mathrm{H} / \mathrm{A}$ z-score) & $649(9.9)$ & $782(14.3)$ & $723(13.4)$ & $205(15.2)$ & $2231(20.4)$ \\
\hline Severe $(<-3 \mathrm{H} / \mathrm{A}$ z-score $)$ & $559(8.6)$ & $822(15.1)$ & $464(8.6)$ & $153(11.3)$ & $4066(37.2)$ \\
\hline
\end{tabular}

$B M I / A=$ body mass index for age, $W / H=$ waist for height, $H / A=$ height for age.

underprivileged groups in the Libyan Arab Jamahiriya and Djibouti (Table 3).

Overall RR for overweight in stunted children was highest in Libyan Arab Jamahiriya (3.85) and lowest in Djibouti (2.14). However, within countries the RR ranged from 0.76 in mildly stunted children in Yemen to as high as 7.15 in severely stunted children in the Libyan Arab Jamahiriya and 11.88 in children in the Hadramout region in Yemen.

RR for overweight was higher among stunted children in rural areas of the Libyan Arab Jamahiriya, Djibouti and Yemen in comparison to urban areas. In the Libyan Arab Jamahiriya, Morocco and Yemen, RR for overweight among stunted children was higher in privileged groups, while in the other 2 countries it was highest in the intermediate socioeconomic groups. The risk increased with age except in the Syrian Arab Republic and Djibouti, where it increased initially but decreased at around 4 years of age. In all countries, the increase in risk was evident with increasing degree of stunting (Table 4). Risk of overweight decreased with increased H/A $z$-score in all countries, but in Yemen it rose sharply again at $\mathrm{H} / \mathrm{A} z$-score $>3$ (Figure 1).
The geographical distribution of risk for overweight within countries was also variable. In the Libyan Arab Jamahiriya, the RR $(95 \%$ confidence interval) ranged from $0.98(0.31-3.10)$ in Sirt region to 5.59 (3.93-7.94) in Tarhuna and Misallata regions. In the Syrian Arab Republic, it ranged from $1.57(0.78-3.18)$ in Daraa to 10.67 (3.65-31.26) in Al-Latakia. In Morocco, the range was from $1.27(0.70-2.31)$ in Doukkala-Abda to 5.58 (3.69-8.46) in Marrakech. In Yemen, the RR was low in Lahej at $0.61(0.27-1.42)$ and increased to 11.88 (1.50-93.93) in Hadramout.

The lowest etiological fraction among stunted children was in Djibouti (53.27\%) and the highest was in stunted children of the Libyan Arab Jamahiriya (73.25\%). In the different subgroups, it was lowest in stunted children in the suburban regions $(28.57 \%)$ and in children younger than 1 year of age (30.07\%) in Djibouti, while the highest etiological fraction among stunted children was in rural areas $(80.27 \%)$ and in children older than 4 years $(81.24 \%)$ in the Libyan Arab Jamahiriya. The etiological fraction in the population as a whole ranged from $23.12 \%$ in Djibouti to $48.42 \%$ in Yemen (Table 5). 


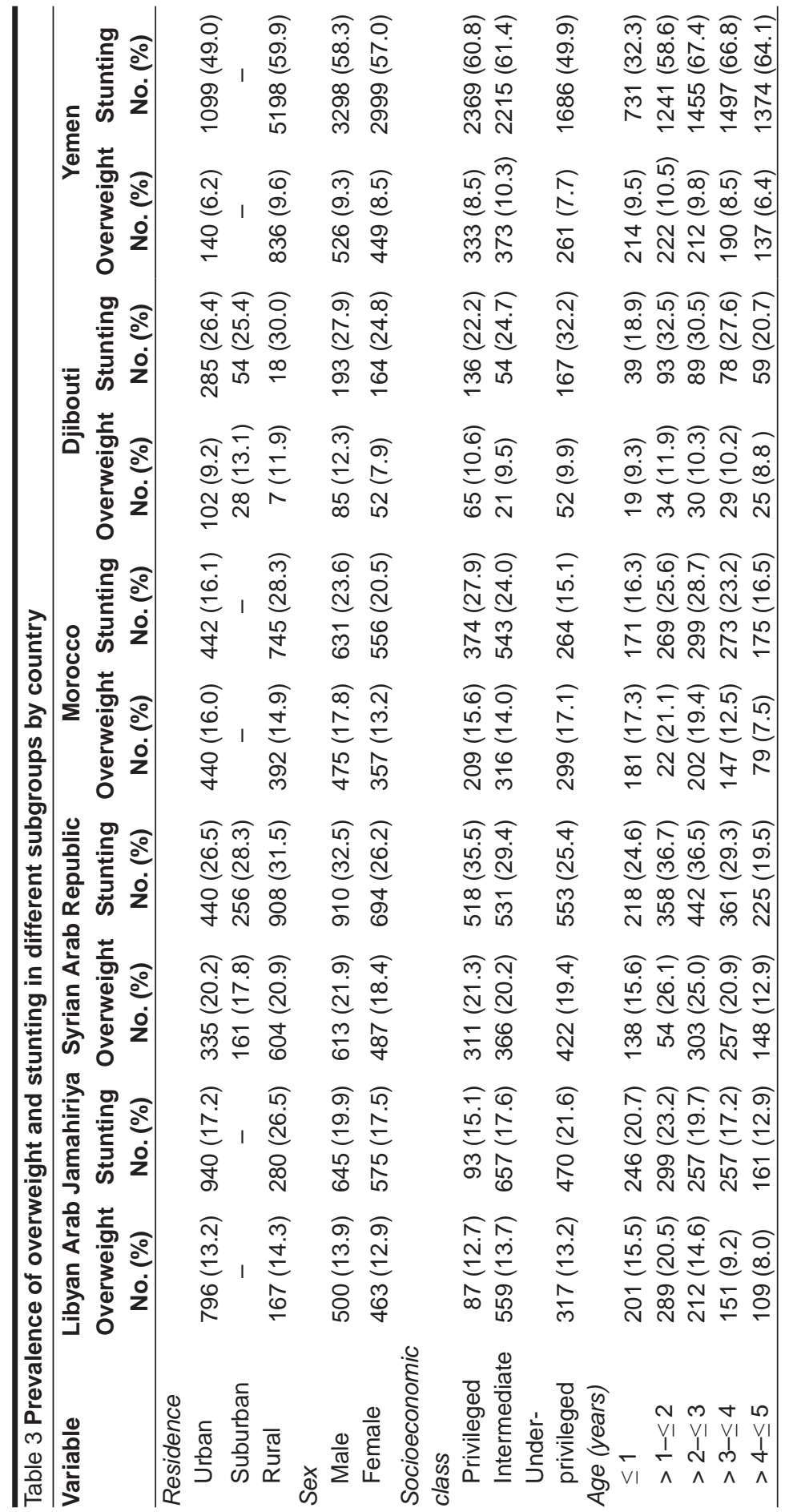

المجلة الصحية لشرق المتو سط، منظمة الصحة العالمية، المجلد الخامس عشر، العدد ب، 9 • • 


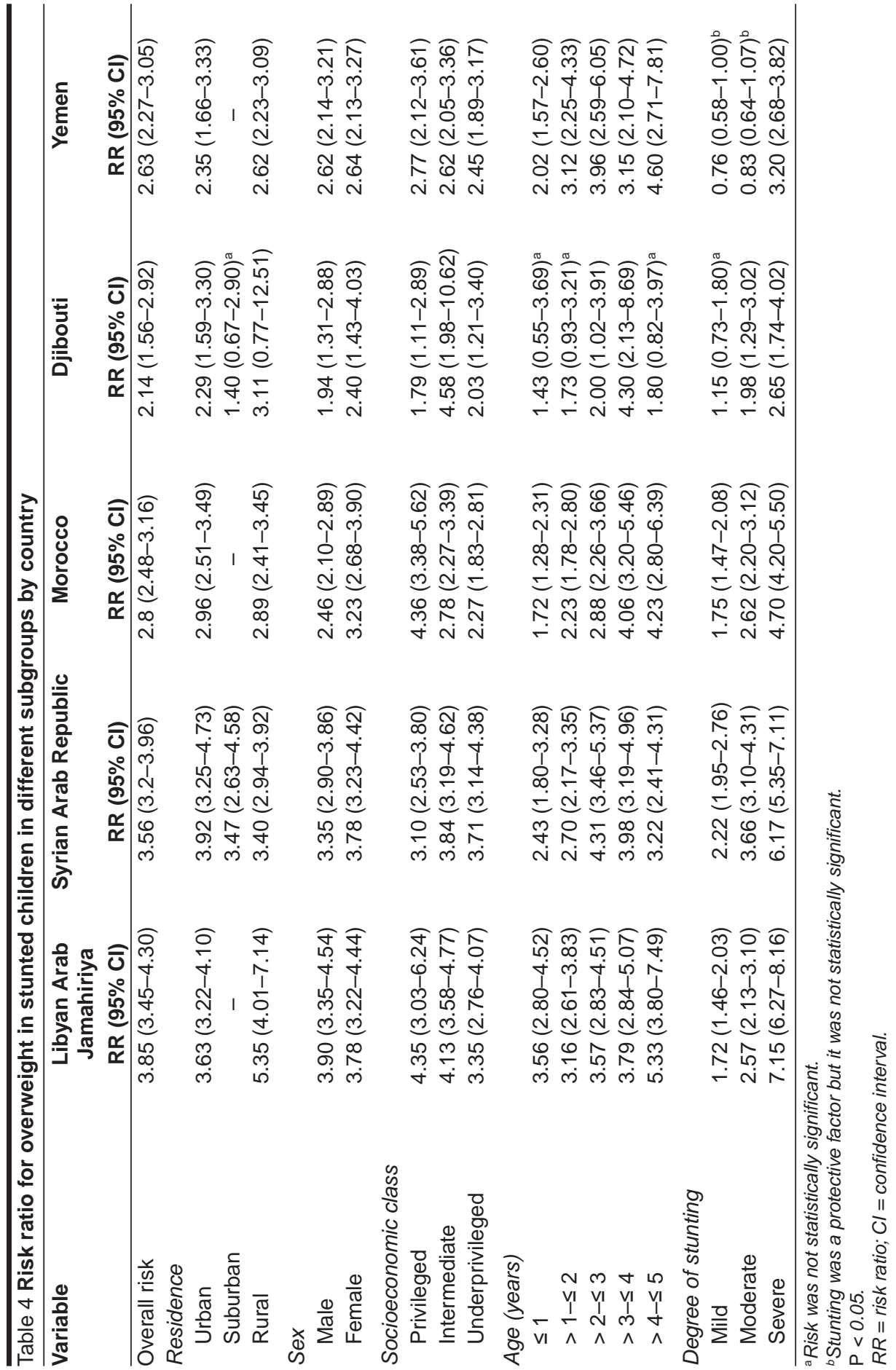

المجلة الصحية لشرق المتوسط، منظمة الصحة العالمية، المجلد الخامس عشر، العدد ؟، 9 .. ب 


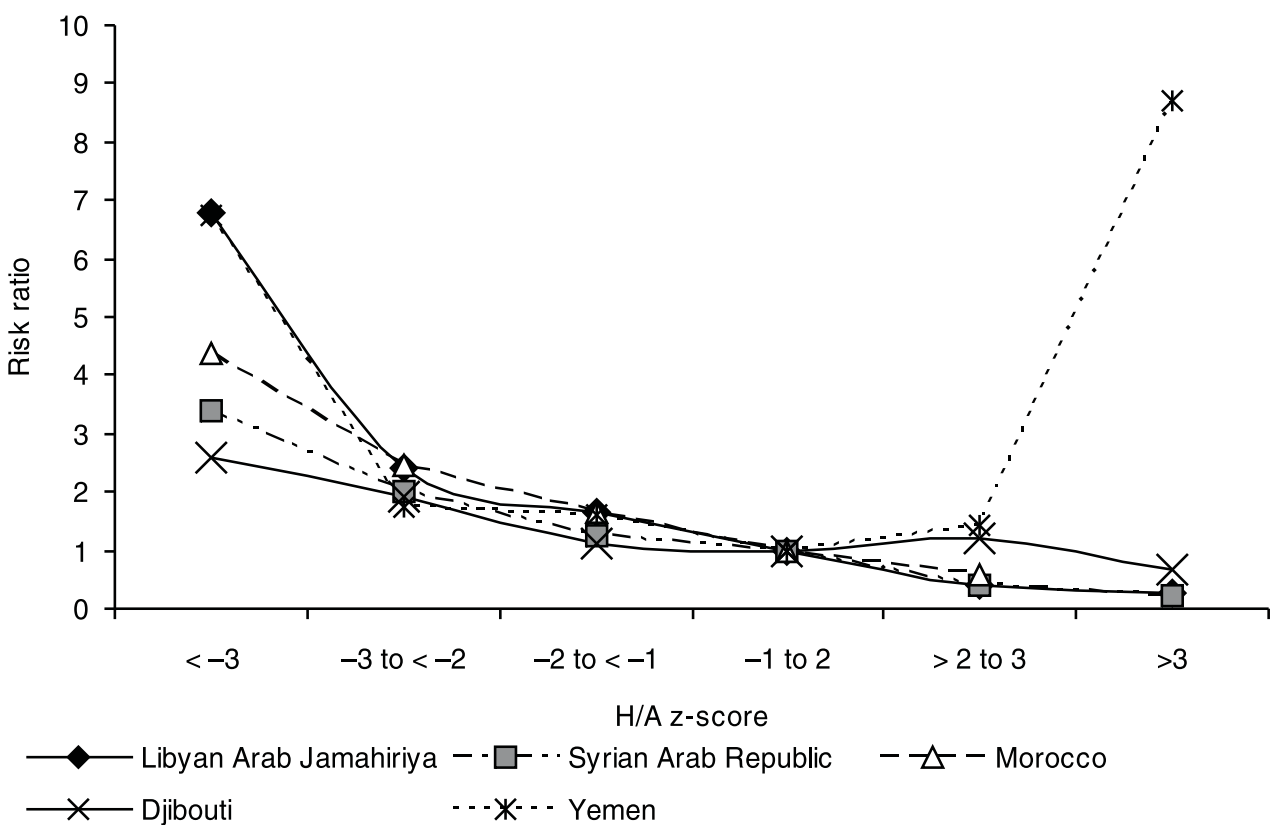

Figure 1 Risk ratio of overweight according to height for age $(H / A) z$-score in 5 Arab countries

\section{Discussion}

Overweight is no longer considered a disease of industrialized nations only. The growing economies and changes in lifestyles in many developing countries, with the accompanying changes in diet and physical activity patterns, have contributed to the appearance of overweight in these countries, while low income, limited choices of food, lack of parks/gardens and public thoroughfares for play and exercise, and inadequate and/or inappropriate education may make it difficult for people to seek and secure healthier foods and lifestyles in these countries [17].

The current study used data from nationally representative surveys to compare the prevalence of both overweight and stunting and to examine the relationship between them in 5 Arab countries that are in various stages of economic transition. These surveys are useful because of the valuable information collected and because of their inter-nation comparability. However, they were primarily established to look for undernutrition rather than overnutrition. No data were collected on variables related to overweight, such as television viewing, maternal nutrition, food practices of the family, or parental weight. Given the current findings, these data should be included in future surveys.

For GDP, we used data from the World Bank rather from national sources. Notably for the Libyan Arab Jamahiriya, the figures given are much lower than figures obtained from authorities in the country (US\$ $>6000$ ). In view of the characteristics of the country, it could be argued that the national figures are probably more representative, but for consistency we kept the source data the same for all the countries. 


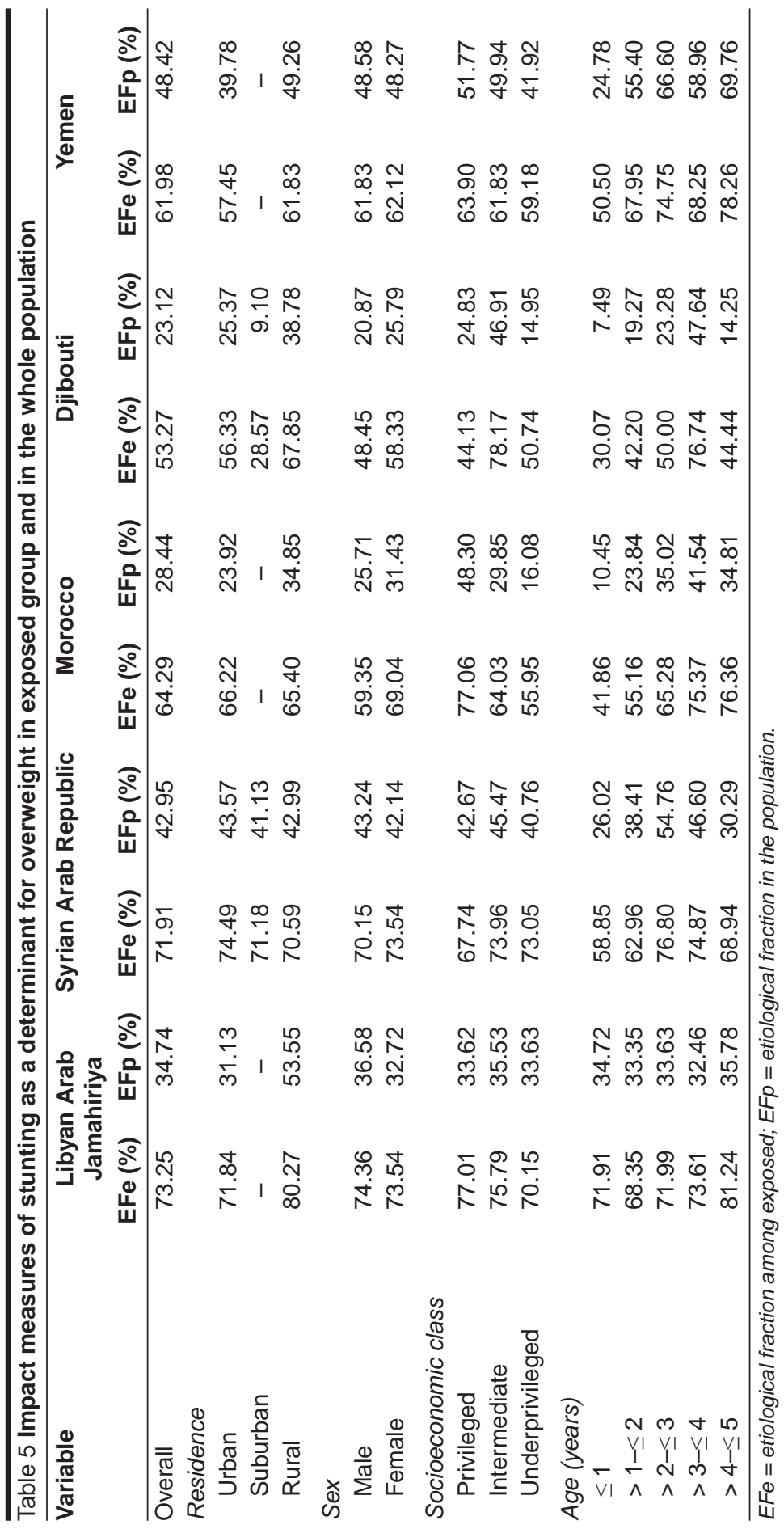

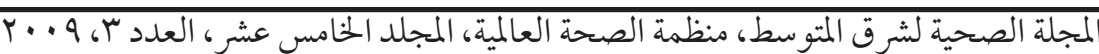


The prevalence of overweight in the current study, even for the lowest prevalence countries $(8.9 \%-20.2 \%)$, was high. In most countries in Africa and Asia, rates of wasting are 2.5-3.5 times higher than rates of overweight [6]. Although the criteria for overweight used in our study were different, BMI/A rather than weight for height, the prevalence of overweight in the Libyan Arab Jamahiriya and the Syrian Arab Republic was much higher than wasting. In Morocco it was also higher but less so, while in Djibouti and Yemen wasting was still more prevalent than overweight.

It is believed that a wide difference in the prevalence of wasting and stunting indicates an early phase of nutritional transition where acute forms (wasting) usually start to decrease first, while in the more privileged countries, both acute and chronic forms show lower prevalence rates [18]. We observed this in the current study as the less privileged countries such as Djibouti and Yemen had high prevalence rates of both forms of undernutrition, while the Syrian Arab Republic and Morocco had low levels of wasting and intermediate levels of stunting, and the Libyan Arab Jamahiriya, with the highest GDP among the studied countries, is classified as a low prevalence area for both wasting and stunting.

The prevalence of overweight and stunting was greater in boys than girls. This has been reported in other studies [19], while the prevalence of overweight for both sexes varies between studies across different ages and ethnic groups [20].

Overweight is related to lifestyle, which is related to urbanization, housing and leisure-time activities. In industrialized nations, overweight is associated with low income and underprivileged groups as these consume more energy-dense but inexpensive foods and they are less engaged in physical activities. In developing countries, overweight is more prevalent in privileged groups [17]. Although this was true for the Syrian Arab Republic and Djibouti, overweight was more frequent in underprivileged groups in Morocco and in intermediate groups in the Libyan Arab Jamahiriya and Yemen. Among possible alternative explanations in our study is that the asset index that we constructed for the current data was not validated in separate studies in these particular populations.

The prevalence of overweight is higher in urban areas than rural or poor urban areas in many developing countries [21]. Urban residence in the current surveys followed locally established definitions in these countries and these are probably not comparable. The relative division in urban areas of worse- or better-off residential areas was not examined in our study. Only 2 of the surveys we used looked at suburban areas as a distinct group. These areas were different in many aspects from both urban and rural areas. Further surveys should systematically include data for suburban and worse- or better-off residential urban areas.

Traditional explanations for the increased risk of overweight associated with stunting observed in developing countries include reduced physical activity and increased high-fat intake. However, increasingly the role of chronic undernutrition in early life is being recognized. Stunting or low H/A is a public health problem worldwide. It measures cumulative deficient growth and is a feature of a complex syndrome including developmental delay, impaired immune function, reduced cognitive function, metabolic disturbances leading to accumulation of body fat, loss of lean mass and increased risk of hypertension [3]. Stunting prevalence is high in developing countries, reaching almost $50 \%$ of children in certain regions of the world [22,23]. Even in industrialized nations like the United States of America, 
at least $5 \%$ of children were reported to be stunted [24].

The relationship between stunting and overweight is not an artefact [25]. BMI is a reliable index of body composition even in stunted children [26].

The deleterious effects of stunting and overweight can start in the uterus and may continue after birth. Both stunting and overweight are related to method of feeding, weaning, and context of eating that would shape future food acceptance and food habits [27]. A number of studies have demonstrated metabolic alterations in children suffering from undernutrition in all tissues and body systems [10]. These alterations are towards energy conservation and maintaining a low metabolism. Stunted children have impaired regulation of food intake and have higher susceptibility to the effects of high-fat diets [28]. When energy intake improves, deposition of fat over time, especially in the abdomen, may result [25]. On the other hand, absence of a relation between stunting and overweight has also been reported [29]. The risk of a stunted child becoming obese did not follow perfectly the increase in prevalence of overweight, nor did it always follow the prevalence of stunting. However, a high prevalence of wasting may decrease the risk of developing overweight, as seen in Djibouti and Yemen, which would also explain the absence of association between these 2 conditions found in another study [21].

There were more intra-country variations in the risk than inter-country variation in our current study. The risk of stuntingoverweight was higher in rural areas and in severe forms of stunting, and variably increased with age. The relation started at even earlier ages in the more privileged countries than was previously noted and was absent at younger ages in countries with a high prevalence of wasting and/or under- weight. Unlike in a previous study [21], we found no difference in RR between boys and girls. Although some studies showed that improved nutrition in conjunction with a decreased prevalence of infections has contributed synergistically to improving linear growth as well as increasing the prevalence of overweight in developed countries $[11,30]$, the finding that increased height was related to overweight only in Yemen is difficult to explain.

Overweight among stunted children depends on the availability of extra energy in a child who was programmed to use energy more economically. Stunting itself is not the direct cause, as many stunted children do not become obese; many stunted children become underweight. The mechanism that leads to overweight in stunted children explains also why we found a higher risk of overweight in stunted children from privileged groups in the Libyan Arab Jamahiriya. Underprivileged groups may have the knowledge, the attitude and the capacity to correct stunting, but unfortunately not always in the most appropriate approach. Yemen and the Syrian Arab Republic had the highest population attributable risk. In Yemen, this was because of the high prevalence of stunting even if the RR was lower than in other countries, while in the Syrian Arab Republic this was due to the high prevalence of overweight and the accompanying RR. Managing stunting in Yemen will prevent almost half the cases of overweight in the population, especially in older children, in rural areas and in underprivileged groups. The highest etiological fraction was in the Libyan Arab Jamahiriya, especially in rural areas and older children.

Findings from the current study indicate that preventive measures, such as public health campaigns on healthy food and encouragement to increase physical activity, should be instituted in the region. Other

المجلة الصحية لشرق المتوسط، منظمة الصحة العالمية، المجلد الخامس عشر، العدد ب، 9 +. 
measures, such as pre-pregnancy and early childhood interventions, should also be directed towards maternal undernutrition, intrauterine growth retardation, compromised lactation and infant feeding [31]. Only a handful of studies have addressed childhood overweight in the region in the last few decades [32-37]. Childhood overweight is not yet high on the agenda of national nutrition programmes in the region [38] but our study suggests that such programmes should incorporate prevention and management, even in those countries with high prevalence of undernutrition.

\section{References}

1. Ezzati M et al. Selected major risk factors and global and regional burden of disease. Lancet, 2002, 360(9343):1347-60.

2. Child growth standards. Geneva, World Health Organization, 2006 (http://www. who.int/childgrowth/en/, accessed 8 October 2008).

3. Branca F, Ferrari M. Impact of micronutrient deficiencies on growth: the stunting syndrome. Annals of nutrition \& metabolism, 2002, 46(Suppl. 1):8-17.

4. Maire B et al. Transition nutritionnelle et maladies chroniques non transmissibles liées à l'alimentation dans les pays en développement [Nutritional transition and non-communicable diet-related chronic diseases in developing countries]. Santé, 2002, 12(1):45-55.

5. Obesity. Preventing and managing the global epidemic. Geneva, World Health Organization, 2000 (WHO Technical Report Series, No. 894).

6. De Onis M, Blossner M. Prevalence and trends of overweight among preschool children in developing countries. American journal of clinical nutrition, 2000, 72(4):1032-9.

7. Murray CJ, Lopez AD. Evidence-based health policy-lessons from the Global Burden of Disease Study. Science, 1996, 274(5288):740-3.

8. The world health report: reducing risk, promoting healthy life. Geneva, World Health Organization, 2002.
9. Uauy R, Kain J. The epidemiological transition: need to incorporate obesity prevention into nutrition programmes. Public health nutrition, 2002, 5(1A):223-9.

10. Sawaya AL, Roberts S. Stunting and future risk of obesity: principal physiological mechanisms. Cadernos de saúde pública, 2003, 19(Suppl. 1):S21-8.

11. Freedman DS et al. Height and adiposity among children. Obesity research, 2004, 12(5):846-53.

12. Pan Arab Project for Family Health (PAPFAM). The League of Arab States. (http:// www.papfam.org/arab_league/default. htm, accessed 7 October 2008).

13. United Nations Children's Fund. Multiple Indicators Cluster Sample Surveys (MICS). Monitoring the situation of children and women: MICS2 questionnaire (http://www.childinfo.org/MICS2/finques/ M2finQ.htm, accessed 30 November 2008).

14. The Libyan National Multiple Indicators Cluster Sample Survey. Preliminary report, the general corpus for planning and health care. Tripoli, General People's Committee, Libyan Arab Jamahiriya, 2003.

15. MGRS. Enrolment and baseline characteristics in the WHO Multicentre Growth Reference Study. Acta paediatrica. Supplementum, 2006, 450:7-15.

16. El-Tajouri RF. Cross sectional study of growth in urban pre-school children in 
Libya [PhD dissertation]. Zurich, Switzerland, University of Zurich, 1979.

17. Caballero B. Introduction. Symposium: Obesity in developing countries: biological and ecological factors. Journal of nutrition, 2001, 131(3):866S-870S.

18. Shgair H AA, Sharshoor S. Nutritional status of children in some Arab countries. In: Arab Congress for Maternal \& Child Health. PAPChild - League of Arab States, 1999.

19. Wamani $\mathrm{H}$ et al. Boys are more stunted than girls in sub-Saharan Africa: a metaanalysis of 16 demographic and health surveys. BMC pediatrics, 2007, 7:17.

20. Wang $Y$, Wang JQ. A comparison of international references for the assessment of child and adolescent overweight and obesity in different populations. European journal of clinical nutrition, 2002, 56(10):973-82.

21. Julia M et al. Influence of socioeconomic status on the prevalence of stunted growth and obesity in prepubertal Indonesian children. Food and nutrition bulletin, 2004, 25(4):354-60.

22. 4th Report on the World Nutrition Situation. Nutrition throughout the life cycle. Geneva, United Nations Administrative Committee on Coordination/Sub-Committee on Nutrition in collaboration with International Food Policy Research Institute, 2000 (http://www.ifpri.org/pubs/ books/4thrpt/4threport.pdf, accessed 8 October 2008).

23. Bwibo NO, Neumann CG. The need for animal source foods by Kenyan children. Journal of nutrition, 2003, 133(11 Suppl. 2):3936S-3940S.

24. Third report on nutrition monitoring in the United States: executive summary. Washington DC, US Government Printing Office, 1995:51 (http://www.cdc.gov/ nchs/data/misc/tronm.pdf, accessed 9 October 2008).
25. Popkin BM, Richards MK, Montiero CA. Stunting is associated with overweight in children of four nations that are undergoing the nutrition transition. Journal of nutrition, 1996, 126(12):3009-16.

26. Hoffman DJ et al. Comparison of techniques to evaluate adiposity in stunted and nonstunted children. Pediatrics, 2006, 117(4):e725-32.

27. Maffeis C. Aetiology of overweight and obesity in children and adolescents. European journal of pediatrics, 2000, 159(Suppl. 1):S35-44.

28. Hoffman DJ et al. Why are nutritionally stunted children at increased risk of obesity? Studies of metabolic rate and fat oxidation in shantytown children from Sao Paulo, Brazil. American journal of clinical nutrition, 2000, 72(3):702-7.

29. Duran $P$, Caballero B, de Onis M. The association between stunting and overweight in Latin American and Caribbean preschool children. Food and nutrition bulletin, 2006, 27(4):300-5.

30. He Q, Karlberg J. BMI in childhood and its association with height gain, timing of puberty, and final height. Pediatric research, 2001, 49(2):244-51.

31. Lukito W, Wahlqvist ML. Weight management in transitional economies: the "double burden of disease" dilemma. Asia Pacific journal of clinical nutrition, 2006, 15(Suppl.):21-9.

32. Moussa MA et al. Factors associated with obesity in school children. International journal of obesity and related metabolic disorders, 1994, 18(7):513-5.

33. Malik M, Bakir A. Prevalence of overweight and obesity among children in the United Arab Emirates. Obesity research, 2007, 8(1):15-20.

34. Al-Nuaim AR, Bamgboye EA, Al-Herbish A. The pattern of growth and obesity in Saudi Arabian male school children. Inter- 
national journal of obesity and related metabolic disorders, 1996, 20(11):1000-5.

35. Jabre $\mathrm{P}$ et al. Overweight children in Beirut: prevalence estimates and characteristics. Child: care, health and development, 2005, 31(2):159-65.

36. Mokhtar $\mathrm{N}$ et al. Diet culture and obesity in northern Africa. Journal of nutrition, 2001, 131(3):887S-892S.

37. Benjelloun S. Nutrition transition in Morocco. Public health nutrition, 2002, 5(1A):135-40.
38. Report on the regional workshop on infant and young child feeding. Casablanca, Morocco, 28-31 July 2003. Cairo, World Health Organization Regional Office for the Eastern Mediterranean, 2003.

39. The World Bank. Countries and Regions [website]. (http://web.worldbank.org/WBSITE/EXTERNAL/COUNTRIES/0,,page PK:180619 theSitePK:136917,00.html, accessed 8 October 2008).

\section{Malnutrition}

Malnutrition remains one of the most serious health problem and the single biggest contributor to child mortality in the Eastern Mediterranean region. A significant proportion of children are undernourished and over a third of the population suffers from micronutrient deficiencies.

Malnutrition is a major contributor to the total global disease burden. More than one-third of child deaths worldwide are attributed to undernutrition. Poverty is a central cause of undernutrition.

A key indicator of chronic malnutrition is stunting - when children are too short for their age group compared to the WHO child growth standards. About 178 million children globally are stunted, resulting from not enough food, a vitamin- and mineral-poor diet, and disease. As growth slows down, brain development lags and stunted children learn poorly. Stunting rates among children are highest in Africa and Asia.

Source: WHO/EMRO Nutrition website (http://www.emro.who.int/nutrition/malnutrition.htm) 